\title{
Minerals profile of forages for grazing ruminants in Pakistan
}

\author{
Farhad Mirzaei
}

Department of Animal Production \& Management, Animal Science Research Institute of Iran, Iran; farmir2001@gmail.com

Received 10 February 2012; revised 15 March 2012; accepted 26 March 2012

\begin{abstract}
The current research was carried out at Rakh Khaire Wala, which is well known as one of the most developed animal husbandry in Punjab, Pakistan. This location in the arid region, where sheep farming is a common practice, was selected for this study. The aim of the study was to determine and collect data on the mineral contents of forages or feedstuffs that are harvested and used in animal nutrition in the region, in order to gain information on the deficiency and/or excess of mineral levels for ruminants grazing therein, fed mainly with these feedstuffs. These pastures were visited twice during the study, in summer and winter, to collect samples in order to determine the effect of seasonal changes on the mineral contents of forages. In each location, samples from the available forages were collected. Forage samples were analyzed in order to determine the $\mathrm{Ca}, \mathrm{Mg}, \mathrm{Na}, \mathrm{K}, \mathrm{Fe}$, $\mathrm{Cu}, \mathrm{Zn}$ and $\mathrm{Mn}$ levels using an Atomic Absorption Spectrophotometer. These results show that pasture grasses/forages had sufficient levels of $\mathrm{K}, \mathrm{Ca}, \mathrm{Mg}, \mathrm{Mn}$ and $\mathrm{Zn}$ to meet requirements of ruminant animals, but the occurrence of marginal to deficient supplies of $\mathrm{Na}$, and $\mathrm{Cu}$ appear very likely. There is an urgent requirement for experimentation on supplementation regimes involving these minerals, so that appropriate recommendations can be formulated.
\end{abstract}

Keywords: Mineral Composition; Forage; Grazing; Pakistan

\section{INTRODUCTION}

All the living systems require inorganic compounds and minerals for normal life sustaining processes. Furthermore, all animal tissues and feedstuffs contain minerals in widely varying amounts and proportions. Unlike other nutrients, minerals can not be synthesized by living organisms; therefore animals must acquire adequate amounts of required elements from their environment if survival and production goals are to be maintained. Livestock usually derive most of their dietary nutrients from the feed they eat, however, significant quantities of minerals may be obtained from water, soil consumption and feed contamination. Feed sources of minerals are typically divided into base feedstuffs (e.g. range or pasture plants, harvested forages, concentrates) and mineral supplements. Efforts to reduce the cost of mineral supplementation in livestock production require a thorough understanding of the supply and availability of mineral nutrients in typical feedstuffs [1].

Voluntary intake and mineral concentrations of base feedstuffs determines the level of mineral consumption. Adequate intake of forages by grazing animals is essential in meeting mineral requirements. Factors that reduce forage intake (e.g. low protein, high degree of lignification) also reduce total mineral consumption. The concentration of minerals in plants is dependent upon interactions among a number of factors including soil type, plant species, stage of maturity, dry matter yield, grazing management and climate [2,3]. Although total concentration of a mineral in a feedstuff is important, the biological availability of the mineral is equally important. Biological availability (absorption and utilization) of minerals varies substantially among animal species and breeds within a species, as well as among feedstuffs. The combination of all of these factors makes it extremely difficult for livestock producers to determine the actual mineral status of their herd, whether or not mineral supplementation is necessary and the degree of supplementation that may be needed to meet production goals [4-6].

Experiments have been previously conducted that address various aspects of mineral nutrition of grazing ruminants. Collectively these studies address seasonal/maturity changes in nutritive quality of native range/pasture plants in southwestern Punjab, Pakistan [7-10]. The effect of forage intake on mineral bioavailability and the effects of water stress, soil fertility, genotype and grazing management on forage chemical composition. The limiting factor in each of these experiments is the high cost of nutrient, particularly mineral, analyses. 
In Pakistan as well as in Asian countries, malnutrition impairs livestock production. Pakistan's overall livestock productivity is below average. Although large number of cattle, sheep and goats are found in Pakistan, the country produces only very small percentage of Pakistan's total meat and milk production respectively. Grazing animals in Pakistan subsist mainly on poor quality feedstuffs in the form of poor quality pastures in arid and semi-arid areas and hays and/or crop residues in the arable areas. In a few of the animal production centers where improved management is undertaken, the main supplements are energy and protein in the form of agro-industrial byproducts such as cereal brans, molasses and oilseed cakes. Scant attention is given to the mineral content and nutritional balance of such diets. It has been widely established that available energy and protein of a feed are of prime importance to any animal but optimal performance is only possible if there is an adequate supply of minerals $[11,12]$. Seasonal variation affects livestock seasonal production in different regions of the world by affecting forage dry matter accumulation. Seasonal forage mineral nutrient contents stability may be achieved through successful breeding programs of forage plants [13]. The primary source of nutrients and their transfer from soil to livestock in rangelands is forage. In Pakistan, ruminants rarely receive mineral supplements except occasionally common salt. Pastures are thus the main source of minerals, and only rarely can forages completely satisfy all mineral requirements of livestock [14]. Hence, it is important to know the mineral-nutrient concentrations of new varieties $[15,16]$. Generally, Fe and Se concentrations increase as the seasonal forage yield increases [17, 18]. In contrast $\mathrm{Cu}, \mathrm{Zn}$, and $\mathrm{Mn}$ contents were not affected by seasonal forage yield [18].

Due to increased demand, improved forage crops such as multi-cut oats, Trifolium, Medicago, Sorghum-Sudan grass hybrids, sorghum, maize and millet have been developed. These have become very popular in irrigated areas such as Kasur, Sheikhupura, Gujranwala, Faisalabad, Sargodha, Jhang and Leiah, and Renala Khurd (Punjab), Nowshera, Charsada, Mardan, and Peshawar(North West Frontier Province), and Hyderabad, Sukkur, Larkana, Halla, and Nawabshah in Sindh, for sale to peri-urban dairies. Therefore, this study was aimed at to evaluate the mineral composition of different forages both in natural pasture and improved varieties in relation to mineral requirement of ruminant in order to adopt various strategies for mineral supplementation for livestock at this semi arid region. This information on forage nutritive values would be useful for Pakistan as well as for other Asian countries with similar climate and ecological conditions.

\section{METERIALS AND METHODS}

Samples of forages and grasses were collected twice from the Livestock experimental station in Punjab, Pakistan from different sites in the pastures of livestock's farm situated away from $450 \mathrm{~km}$ southwest of Islamabad, the capital of Pakistan at Meteorological conditions described in Table 1. All the samples were from the natural pastures and were obtained by pooling core samples from three positions within the pasture. The species collected included: Cynodon dactylon, Cynodon plectostachum, Pennisetum purporeum, Andropogon gayanus, Acacia brevispica and-Posopis cineraria, Lolium multiflorum, Sorghum sudanense, Pennisetum americanum, Vigna radiate, Panicum miliaceum, Vigna aconitofolia Paspalum conjugatum, Drymaria cordata and improved pasture hay Medicago spp. were taken as described above from stacks of forages at these sites harvested in June and August during summer and January and February during winter season, 2006.

Albizzia lebbek grown at the farm for grazing livestock in pasture of that specific site were harvested in February, 2006. Samples were taken by pooling leaves from mature trees. Leaves from the trees in the pastures were further separated into young and old. Pods with seeds on trees from the pasture were first air-dried and then separated into pods and seeds. Samples of Salvdora oleoides were taken in February, 2006 from a plain lower area at a Government research station in the pasture. The Prosopis spp. samples were of the species mainly browsed by the browsing ruminants. Samples of forages remains were taken using the same procedures as for other forages. The forages residues were of natural pasture and improved varieties of forages grown therein, and most of them were being used in feeding experiments at Livestock experimental station.

Table 1. Meteorological conditions (Mean \pm SD) recorded during the experimental periods.

\begin{tabular}{cccccccc}
\hline & \multicolumn{3}{c}{ Winter } & \multicolumn{3}{c}{ Summer } \\
\hline & Temperature $\left({ }^{\circ} \mathrm{C}\right)$ & Relative humidity (\%) & THI & & Temperature $\left({ }^{\circ} \mathrm{C}\right)$ & Relative humidity (\%) & THI \\
\hline Day & $11.8 \pm 2.9$ & $67.9 \pm 19.5$ & $53.7 \pm 4.6$ & Day & $47.9 \pm 4.8$ & $41.8 \pm 12.3$ & $79.4 \pm 2.7$ \\
Night & $6.8 \pm 3.9$ & $85.6 \pm 13.7$ & $44.6 \pm 6.3$ & Night & $21.8 \pm 4.6$ & $52.2 \pm 12.6$ & $55.5 \pm 5.8$ \\
\hline
\end{tabular}

THI is the Temperature Humidity Index calculated as follows: THI $=04$ (dry-bulb thermometer temperature ${ }^{\circ} \mathrm{F}+$ Wet-bulb thermometer temperature $\left.{ }^{\circ} \mathrm{F}\right)+15$. 


\subsection{Chemical Analysis}

The dried samples were ground using a one-mm sieve and stored in plastic bottles ready for preparation. Samples were prepared for mineral analysis by the wet digestion method using concentrated sulphuric acid in presence of hydrogen peroxide. The concentrations of $\mathrm{K}, \mathrm{Na}$, $\mathrm{Ca}, \mathrm{Mg}, \mathrm{Fe}, \mathrm{Mn}, \mathrm{Zn}$ and $\mathrm{Cu}$ were determined by Atomic Absorption Spectrophotometer [19] .

\subsection{Statistical Analysis}

The data thus obtained during the study were analyzed by Statistical Analysis System (SAS, 1987, Statistical Analysis System. Version 6.03. SAS Institute, North Canolina, USA). Significance levels ranged from 0.05 0.001 for statistical analysis .Differences between means were ranked using Duncan's New Multiple Range Test [20].

\section{RESULTS AND DISCUSSION}

The total mineral content of feedstuffs is called ash. Forages normally contain $3 \%$ to $12 \%$ ash on a DM basis. Organic matter is determined by subtracting ash from 100. Minerals can be divided into two groups. Macro are those required by animals in relatively large amounts and include calcium, phosphorus, potassium, magnesium, sulphur, and salt (sodium chloride) while micro or trace minerals are required in small amounts and include iron, iodine, cobalt, copper, manganese, zinc, and selenium. It has been recommended that forages should be routinely tested for calcium and phosphorus. Other macro minerals, along with trace minerals, should be tested for once or twice per year to identify the imbalances in their concentrations. The analytical results for all forages and grasses as related to requirements of ruminants are presented in Tables 2-4.

Table 2. Mineral content of some dried leaves of different grasses from southwestern ranch in Punjab, Pakistan.

\begin{tabular}{|c|c|c|c|c|c|c|c|c|}
\hline \multicolumn{9}{|c|}{ Forages } \\
\hline \multirow{2}{*}{ Description of dried leaves samples } & \multicolumn{4}{|c|}{ Macro minerals (g/Kg) } & \multicolumn{4}{|c|}{ Micro minerals (mg/Kg) } \\
\hline & $\mathrm{K}$ & $\mathrm{Na}$ & $\mathrm{Ca}$ & $\mathrm{Mg}$ & $\mathrm{Fe}$ & $\mathrm{Mn}$ & $\mathrm{Zn}$ & $\mathrm{Cu}$ \\
\hline Wheat & 20.50 & 0.70 & 3.40 & 2.30 & 712.00 & 217.00 & 48.00 & 6.40 \\
\hline Barley & 15.70 & 0.60 & 5.30 & 1.90 & 894.00 & 215.00 & 41.00 & 6.80 \\
\hline Oats hay & 16.40 & 0.17 & 1.80 & 1.65 & 265.00 & 106.00 & 35.00 & 7.00 \\
\hline Cynodon & 21.30 & 2.13 & 5.87 & 2.15 & 421.00 & 219.00 & 38.00 & 8.80 \\
\hline Medicago & 25.80 & 1.70 & 4.12 & 2.90 & 388.00 & 246.00 & 34.00 & 8.12 \\
\hline Trifolium & 19.80 & 0.90 & 5.23 & 2.30 & 210.00 & 278.00 & 33.00 & 7.80 \\
\hline Mixed & 15.40 & 0.80 & 5.34 & 2.17 & 608.00 & 334.00 & 45.00 & 8.30 \\
\hline Andropogon & 27.90 & 1.67 & 2.13 & 1.80 & 850.00 & 48.00 & 27.00 & 4.20 \\
\hline Paspalum cojugatum & 1.40 & 0.15 & 4.17 & 1.76 & 643.00 & 78.00 & 37.00 & 3.70 \\
\hline Cynodon plectostachchyum & 1.20 & 0.06 & 2.42 & 1.80 & 912.00 & 67.00 & 36.00 & 6.30 \\
\hline Pennisetum purporeum & 1.40 & 0.15 & 3.50 & 2.23 & 472.00 & 78.00 & 45.00 & 5.30 \\
\hline
\end{tabular}

Table 3. Mineral concentration of some forage residues from the farm in Punjab, Pakistan.

\begin{tabular}{|c|c|c|c|c|c|c|c|c|}
\hline \multirow{2}{*}{ Samples description } & \multicolumn{4}{|c|}{ Macro minerals (g/Kg) } & \multicolumn{4}{|c|}{ Micro minerals (mg/Kg) } \\
\hline & $\mathrm{K}$ & $\mathrm{Na}$ & $\mathrm{Ca}$ & Mg & $\mathrm{Fe}$ & $\mathrm{Mn}$ & $\mathrm{Zn}$ & $\mathrm{Cu}$ \\
\hline Lolium multiforum & 14.80 & 0.30 & 4.10 & 1.50 & 325.00 & 78.00 & 11.00 & 3.00 \\
\hline Sorghum sudanese & 10.70 & 0.50 & 4.60 & 1.40 & 117.50 & 90.00 & 12.00 & 5.00 \\
\hline Pennisetum americanum & 11.70 & 0.30 & 4.30 & 1.90 & 170.00 & 59.00 & 26.00 & 6.50 \\
\hline Vigna radiate & 17.70 & 0.40 & 3.90 & 1.80 & 196.00 & 191.00 & 17.00 & 14.00 \\
\hline Panicum miliaceum & 10.70 & 0.60 & 7.70 & 2.20 & 103.00 & 71.00 & 24.00 & 14.00 \\
\hline Vigna aconitofolia & 17.80 & $0 / 50$ & 3.30 & 2.50 & 408.00 & 61.00 & 24.00 & 5.90 \\
\hline
\end{tabular}


Table 4. Mineral content of Salvodora oleiodes, Albizzia lebek, and Prosopis cineraria at ruminant ranch.

\begin{tabular}{lcccccccc}
\hline & \multicolumn{9}{c}{ Salvodora oleiodes } \\
\hline \multirow{2}{*}{ Description of dried leaves samples } & \multicolumn{3}{c}{ Macro minerals (g/Kg) } & \multicolumn{3}{c}{ Micro minerals (mg/Kg) } \\
\cline { 2 - 10 } & $\mathrm{K}$ & $\mathrm{Na}$ & $\mathrm{Ca}$ & $\mathrm{Mg}$ & $\mathrm{Fe}$ & $\mathrm{Mn}$ & $\mathrm{Zn}$ & $\mathrm{Cu}$ \\
\hline Young leaves & 25.60 & 0.45 & 4.70 & 2.80 & 194.00 & 38.00 & 43.00 & 13.80 \\
Old leaves & 19.32 & 0.43 & 20.76 & 4.32 & 223.00 & 65.00 & 24.00 & 13.50 \\
Small new branches & 15.80 & 0.76 & 17.87 & 1.50 & 206.00 & 45.00 & 16.00 & 4.80 \\
Fruits & 17.70 & 0.54 & 4.80 & 2.34 & 154.00 & 34.00 & 49.00 & 14.67 \\
\hline & & & Albizzia lebbek & & & & & \\
\hline Small twigs with leaves & 15.00 & 1.80 & 23.3 & 3.50 & 244.00 & 155.00 & 52.00 & 11.40 \\
Pods with seeds & 23.80 & 1.80 & 8.50 & 1.90 & 114.00 & 48.00 & 35.00 & 7.60 \\
Pods alone & 15.70 & 1.70 & 15.50 & 1.40 & 592.00 & 58.00 & 42.00 & 7.80 \\
Old and young leaves & 17.20 & 1.80 & 31.76 & 5.40 & 295.00 & 445.00 & 66.00 & 7.90 \\
Prosopis cineraria & 19.70 & 1.25 & 8.90 & 3.60 & 188.00 & 154.00 & 53.00 & 7.50 \\
\hline
\end{tabular}

\subsection{Potassium}

In this investigation the level of $\mathrm{K}$ in all the forages was above $8 \mathrm{~g} / \mathrm{kg}$ recommended for grazing animals [21]. It has, however, been suggested that some ruminants with high producing, under stress such as heat stress, may require K level above $10 \mathrm{~g} / \mathrm{kg}$. Since only the residues of some forage crops approached this level [2,12], it seems most unlikely that problems of $\mathrm{K}$ deficiency are likely to arise. It tended to be higher in some forage samples during this investigation. Similar K concentrations were also reported [22,23]. High potassium forages and low sodium chloride diets are seemingly contributing to reproductive losses in herbivores. Excessive potassium in forages induces deficiency of other minerals and immune suppression. There appears to be a causal relationship between high potassium forages and a multitude of emerging opportunistic diseases of livestock.

In recent years it has become apparent that excessive potassium in the diet is a primary and significant cause of mineral antagonisms and induced imbalances in herbivores. This is certainly not a new discovery and it has been reported nearly 50 years ago, but potassium levels in forages have increased dramatically since that time and are continuing to increase. Environmental factors play an important role in potassium metabolism in plants. Potassium is naturally high in lush grass during the early grass-growing season especially when environmental conditions like high moisture and heat favor rapid grass growth. Since potassium is the cation responsible for naturally protecting plants from droughts as well as from frost damage it is reasonable to assume that an increase in forage potassium may occur during and after frost damage to plants. To further complicate the cation imbalance, excess potassium antagonizes the uptake of so- dium that has become naturally deficient in forages. When herbivores consume these high potassium-low sodium forages, acute electrolyte and mineral imbalances may occur if they do not have readily available supplemental sodium chloride to counteract the high potassium in forages [24] .

Potassium in plants forms weak complexes and can substitute for similar cations, primarily sodium, and thus affect the sodium chloride or salt requirements for animals. An excess of potassium, and a deficiency of sodium, may alter the balance of all other cations and anions. Importantly, excess potassium can interfere with the uptake and availability of sodium, calcium and magnesium in the diet and may interfere with both magnesium and calcium metabolism. When potassium spikes in forages, the anions chloride and sulfate may also increase which further exacerbates the imbalances of cations in forages. An excess of chloride may influence calcium metabolism and cause excessive excretion and a calcium deficiency may occur. An excess of sulfates may interact with selenium and can cause a selenium deficiency [25]. Also, when there is a calcium deficiency, toxicosis from all minerals, essential and non-essential, is more likely to occur. The end result is cascading mineral imbalances, secondary toxicoses, and induced deficiencies of essential trace and macro minerals.

When animals are exposed to high potassium forages, they display signs of salt deprivation and aggressively devour sodium chloride to counteract the excessive potassium in forages. This may occur with any forage, but is especially common if herbivores consume rapidly growing lush grass and legumes. Also, it may occur if animals are fed hay high in potassium or if cattle are foraging corn stalks after the corn was heavily fertilized with either high potassium manure or high potassium 
fertilizers. The salt deprivation behavior is especially apparent if herbivores are devoid of supplemental salt for only a short period of time [26].

In addition to grass, tetany which is commonly seen in cattle, other herbivores, including horses, sheep and goats exposed to high levels of potassium may suffer from a multitude of disease syndromes. These include reproductive losses with abortions occurring during all stages of pregnancy, premature births, and weak offspring at birth. The high potassium may cause an antagonism to other minerals, and multiple mineral imbalances and induced deficiencies may occur. When this occurs, animals become susceptible to opportunistic diseases, which may also contribute to additional reproductive diseases of livestock. Potassium in different growing forages is usually quite high [27]. Potassium levels of $0.6 \%$ to $0.8 \%$ of ration dry matter are considered adequate for cattle. In general, potassium levels of Ohio forages are adequate to excessive in potassium content. These high levels can be associated with reducing magnesium absorption and thus causing grass tetany problems. Therefore, always check potassium levels before any supplemental additions is recommended. Low concentrations of potassium have been observed in most of the forages during the winter [7]. Leaching during the winter may cause potassium levels in forages pasture to drop as low as $0.24 \%-0.3 \%$ of dry matter during winter months. Potassium can be supplemented to cattle in the forms of readily available diets such as potassium chloride, potassium bicarbonate, potassium sulfate, or potassium carbonate. If potassium is added for winter feeding, then it must be removed from the mixture when forages start growing in the spring. Growing forages are usually high in potassium. Thus, the grazing livestock consuming primarily a forage diet would receive adequate $\mathrm{K}$. In certain regions of the world, it is possible that $\mathrm{K}$ deficiency could arise, in view of decreasing content of this mineral with increasing forage maturity [7].

\subsection{Iron}

The forage contained Fe contents in almost all the forages samples studied were above the levels of 50 $\mathrm{mg} / \mathrm{kg}$ proposed as adequate for grazing animals $[9,12]$. Variations in the contents of $\mathrm{Fe}$ among grazing forages could be partly explained by forage species' differences and the influence of grazing lands on the level of $\mathrm{Fe}$ in the soil. All the grazing pasture forages had higher levels of Fe than the critical content of $\mathrm{Fe}$ in animal tissues (30 - $\left.50 \mathrm{mg} \cdot \mathrm{kg}^{-1} \mathrm{DM}\right)$. Differences in the contents of Fe between the grazing different pastures forages and literature values could also be related by variations in the content of Fe in the soil, and climatic conditions between localities. Forage Fe content is a function of forage spe- cies, soil Fe content, nature and type of soil on which forages are grown $[16,28]$. These forages had higher levels of Fe than the normal requirements of 30 - $60 \mathrm{mg} \mathrm{Fe}$ $\mathrm{kg}^{-1} \mathrm{DM}$ of ruminants [16]. However, Fe bioavailability in ruminants would depend on feed mixture fed together and form of Fe in these feeds. Forage Fe levels during the study season were sufficient for the requirements of ruminants for optimal performance. These levels of forage Fe in the present study may support the reports of various researches [22,29-31]. The generally high forage $\mathrm{Fe}$ found in this study is an agreement with the higher forage Fe value of $650 \mathrm{mg} / \mathrm{kg}$ reported in the similar region in Pakistan [7]. The changing conditions of soil and climate as well as physiological state of plants affect the $\mathrm{Fe}$ absorption by the plants [32].

\subsection{Manganese}

High levels of manganese in forage can retard the growth of livestock. The feasibility of breeding for lower manganese concentration in shoots of various forages was examined growing in acid, manganiferous soil. Sampling leaves of a particular physiological age in a field-growing breeding population provided an adequate indicator of manganese concentrations in whole shoots. Forage Mn levels were above $40 \mathrm{mg} / \mathrm{kg}$, the critical level and found to be sufficiently higher to meet the requirements of ruminants. Similar levels of forage Mn concentrations have already been reported [22,30,31,33] .

It has been reported that low soil Co level found in this research work was also a possible explanation of high level of $\mathrm{Mn}$ in forage as these elements antagonize in the soil $[10,34,35]$. Mean forage Mn concentrations were although high but below the maximum tolerable levels [36]. Most of the ruminants and particularly rams fed the least amount of manganese had low concentrations of manganese in heart and lung and a lower activity of manganese superoxide dismutase in heart than rams fed $45.8 \mathrm{pg} \mathrm{Mn} / \mathrm{g}$ dry matter. The concentration of manganese in these tissues, and the activity of manganese superoxide dismutase in the heart increased linearly as the concentration of manganese in the forage consumed by these animals increased. An intake of $13.8 \mathrm{pg} \mathrm{Mn/g}$ of dry matter therefore caused some biochemical changes in rams, but was adequate for growth and wool production under the conditions of this experiment. Influence of manganese intake on body, wool and testicular growth of young rams and on the concentration of manganese and the activity of manganese enzymes in tissues is dependent on forage or diet Mn levels [37].

\subsection{Sodium}

The Na requirement for ruminants is often debated in the literature concerning the dietary concentration de- 
mand of the animals. An adequate range from 1 - $4 \mathrm{~g} / \mathrm{kg}$ has been recommended by various researchers [21]. The present data show that with the exception of Albizzia lebbek, most of the forage samples examined were very poor sources of $\mathrm{Na}$, such that routine supplementation is likely to be necessary. These values were deficient because of being lower than the critical values (requirement of ruminants) [33,38-40]. This widespread deficiency in forage $\mathrm{Na}$ is corroborated with some earlier findings that the most prevalent mineral deficiencies for grazing animals in world were $\mathrm{Na}$ [33,38-40]. In addition, deficiency of this element has been reported in many developing countries [41].

Sodium concentrations in forages were below the levels recommended for optimal animal productivity and production. .It has been suggested that a sodium intake of $0.87 \mathrm{~g} / \mathrm{kg}$ was required to maintain an adequate $\mathrm{Na}$ and $\mathrm{K}$ ratio in the parotid saliva of ewe's, It was also reported that milk production and lamb growth were unaffected by intakes, the ewes were in negative sodium balance. The content of $\mathrm{Na}$ in the ration is important in determining the adequacy of the minerals. To meet the need of highly productive animals, forage should contain more than $0.15 \%$ sodium. Na deficiency is more likely to occur in animal grazing tropical pasture species and these plants generally accumulate less $\mathrm{Na}$ than temperate species [42]. Natural forages low in Na has been reported in numerous tropical countries throughout the world [12].

\subsection{Calcium}

Forage Ca concentrations of 2 - $6 \mathrm{~g} / \mathrm{kg}$, with higher requirements for lactation have been variously recommended for cattle and sheep $[34,43,44]$. Variations in the levels of Ca between findings in this study with values reported in the literature could be partly explained by different forage species, species composition, stage of maturity and season, and variations in soil characteristics due to location of the different grazing pastures at the ruminant ranch in this arid region of Punjab-Pakistan. Higher contents of Ca could probably be explained by proportion of forage species. Forages that were used in this study were harvested to include a mixture of grasses crop residues and legumes species that form the major portion of the diet consumed by grazing ruminants. In this region it could be assumed that legumes contain more minerals concentrations than would be in grass species, forage crop residues and legumes during winter seasons, which are richer in minerals, including Ca than stem fractions of grasses [41,45-47]. Mean forage Ca concentrations were adequate and sufficiently higher than the requirements of ruminants. Forage Ca requirements of grazing ruminants is a subject of considerable debate as the requirement is influenced by animal type and level of production, age and weight. It has been sug- gested Ca requirement for maintenance, growing and lactating sheep to be $1200-2600 \mathrm{mg} / \mathrm{kg}$ [48]. Thus the forage Ca values found in this study was considered adequate for the optimum performance of ruminants. Similar forage Ca values as found in summer were reported $[17,23,29,49]$. These results indicate that problems of Ca deficiency would not be expected.

\subsection{Magnesium}

The native and un improved pasture forages had lower levels of $\mathrm{Mg}$ than most species of forages and grasses However, differences in the content of $\mathrm{Mg}$ in this study with those in the literature could be partly explained by differences between forage species, level of $\mathrm{Mg}$ in the soil, influences of locality and climate, growth stage, proportion of leaf and stem fractions collected for mineral analysis, and season when forage sampling was done. The grazing pasture forages had slightly higher levels of $\mathrm{Mg}$ than the recommended requirement [25,43]. These forages would therefore meet the theoretical requirement of $\mathrm{Mg}$ for beef cattle and for lactating cows $(1.2-2.1 \mathrm{~g} /$ $\mathrm{kg}$ DM) [50]. These forages had also higher levels of $\mathrm{Mg}$ than the recommended requirements for growing lambs and lactating ewes and goats [51]. Similar values in winter forage Mg were reported [52]. Grass tetany is most common in lactating cows grazing lush spring pastures. During the early spring, climatic and soil conditions are cool and wet; plants will not contain adequate levels of phosphorus or magnesium [7]. While both these minerals may be in adequate amounts in the soil, plant uptake is slow due to the cool, wet conditions. Fertilizing pastures with nitrogen and potassium is associated with increased incidence of grass tetany. Cows depend on a frequent supply of magnesium from the feed since mobilization of magnesium from the bone is not very efficient.

The dietary $\mathrm{Mg}$ availability to stock is markedly affected by other dietary components, especially K. High dietary levels of $\mathrm{K}$ and $\mathrm{N}$ will inhibit $\mathrm{Mg}$ absorption from the rumen. Ca and soluble carbohydrates may respectively increase and decrease dietary $\mathrm{Mg}$ requirements of livestock, whereas raised dietary P levels appears to lower the requirements for both $\mathrm{Ca}$ and $\mathrm{Mg}$ [53-56].

\subsection{Zinc}

It has been suggested that $30 \mathrm{mg} / \mathrm{kg}$ to be a critical level of dietary $\mathrm{Zn}$, although it has been recommended that concentrations of $12-20 \mathrm{mg} / \mathrm{kg}$ are adequate for growing ruminants [43]. The forages remains/residues may thus constitute a marginal supply of $\mathrm{Zn}$ the necessity for supplementary Zn needs to be kept under review particularly for goats and sheep in addition to cattle, which require some $35 \mathrm{mg} \mathrm{Zn/kg} \mathrm{diet} \mathrm{[27].} \mathrm{The} \mathrm{Zn}$ content in these forages could be sufficient for recommended re- 
quirement for sheep. However, efficiency of Zn utilization of these forages would depend on zinc bioavailability, and its interaction with other mineral elements. Forage $\mathrm{Zn}$ concentration was also found above the requirements of ruminants during in winter [48]. Almost similar results were reported [22,23]. A number of factors including soil, plant species, pasture management, and climate, may affect the likelihood of Zn deficiency in ruminants. It has been reported the low level of $\mathrm{Zn}$ in soil and plants [55]. Plant maturity has also been reported to affect $\mathrm{Zn}$ concentration of forage and it also depends upon the tissue type of plants [21,32].

\subsection{Copper}

It is commonly suggested that the dietary requirement of ruminants for $\mathrm{Cu}$ ranges from 8 to $14 \mathrm{mg} / \mathrm{kg}[15,38]$. In this investigation the most of the forage samples analyzed are only meeting the marginal to deficient requirements of this element. This situation may be even further complicated by high levels of dietary Fe which can be elevated by soil ingestion during grazing. It has been also found that dietary concentrations exceeding $1 \mathrm{~g}$ $\mathrm{Fe} / \mathrm{kg}$ can profoundly reduce the availability of ingested $\mathrm{Cu}$; relatively slight and doubtless common levels of dietary soil contamination can produce Fe concentrations of this order, necessitating the serious consideration of providing supplementary $\mathrm{Cu}$ to the grazing livestock $[33,57]$. Forage $\mathrm{Cu}$ content declines with forage maturity, and is higher in leaf vs. stem fractions. Copper deficiencies in forages can cause poor reproduction, broken bones, weak calves, and light color hair. Discoloration normally occurs first around the eyes and tips of the ears. Sometimes, changes in hair color are not noted and the effect of a copper deficiency simply occurs as reproductive problems, scours, or calves older than four months ceasing to perform. Simmental and Charolais cows and their calves were more susceptible to copper deficiency than Angus cows fed the same diet [58].

It is worth mentioning that forage may contain an adequate level, however, if the diet contains either high levels of molybdenum (2 ppm) or sulphur $(0.25 \%)$, both of these tie-up copper, rendering a deficiency. Ideally, the copper to molybdenum ratio should be around 5:1. Legumes were blamed for increasing the molybdenum levels on reclaimed strip ground in Montana. High concentrations of iron and zinc also reduce copper status and may increase copper requirements [33,59,60].

\section{CONCLUSION}

The minerals most widely present in inadequate amounts are $\mathrm{Na}$, and $\mathrm{Cu}$. It is stressed that data of the type presented here can provide only an indication of the existence of potential mineral deficiency problems, since animal selectivity usually results in the consumption of material of somewhat higher quality than that of the total available, and conclusive diagnosis must be based on the occurrence of a positive response to supplementary supply of the mineral in question. However, such data are vital in the formulation of critical supplementation experiments. There is an urgent need for appropriate experimentation so that soundly-based supplementation packages can be devised.

\section{REFERENCES}

[1] Dost, M.A., Khan, H.S. and Bhatti, M.B. (1990) Locational differences in forage yield and quality of maize cultivars. Pakistan Journal of Scientific and Industrial Research, 33, 454-456.

[2] Khan, Z.I., Hussain, I.A., Ashraf, M., Valeem, E.E. and Javed, I. (2005) Evaluation of variation of soil and forage minerals in pasture in a semiarid region of Pakistan. Pakistan Jounal of Botany, 37, 921-931.

[3] McDowell, L.R., Conrad, J.H., Ellis, G.L. and Loosli, L.K. (1983) Minerals for grazing ruminants in tropical regions. Extension Bulletin 1149, Animal Science Department, University of Florida, Gainseville.

[4] Dost, M. (1997) End of assignment report on forage component. FAO/PAK/86/027 Gilgit, Pakistan.

[5] Dost, M.A., Khan, H.S. and Bhatti, M.B. (1990) Locational differences in forage yield and quality of maize cultivars. Pakistan Journal of Scientific and Industrial Research, 33, 454-456.

[6] Dost, M. (2001) Fodder success story-Improved fodder crop production in the Northern Areas of Pakistan. Integrated Crop Management, 4, AGPC/FAO, 23.

[7] Khan, Z.I. (2003) Effect of seasonal variation on the availability of macro-and micro, nutrients to animals (sheep and goats) through forage from soil. Ph.D Thesis, University of Agriculture, Faisalabad, 286.

[8] Khan, Z.I., Hussain, I.A., Ashraf, M. and McDowell, L.R. (2006) Mineral status of soils and forages in Southwestern Punjab-Pakistan: Micro-minerals. Asian-Australian Journal of Animal Science, 19, 1139-1147.

[9] Khan, Z.I., Hussain, I.A., Ashraf, M., Valeem, E.E. and Javed, I. (2005) Evaluation of variation of soil and forage minerals in pasture in a semiarid region of Pakistan. Pakistan Journal of Botany, 37, 921-931.

[10] Khan, Z. I., Ashraf, M. and Hussain, A. (2007) Evaluation of manganese status of grazing sheep in a semi-arid region of Pakistan. Trace Elements and Electrolytes, 24, 5560.

[11] Khan, Z.I., Hussain, A., Ashraf, M., Valeem, E.E. and Akhtar, M.S. (2004) Seasonal variation in soil and forage mineral concentrations in a semiarid region of Pakistan. Pakistan Journal of Botany, 36, 635-640.

[12] McDowell, L.R. (1985) Nutrition of grazing ruminants in warm climates. Academic Press, New York, 443.

[13] Mislevy, P., Sinclair, T. and Ray, J.D. (1999) Improving 
forage productivity during late fall and early winter by making grass less sensitive to short days. Agronomy Department Bulletin, No. 748, Department of Agronomy, University of Florida, Gainseville.

[14] Miles, E.H. and McDowell, L.R. (1983) Mineral deficiencies in the Llanos rangelands of Colombia. World Animal Review, 46, 2-10.

[15] Khan, Z.I., Ashraf, M., Hussain, A. and McDowell, L.R. (2006) Concentrations of minerals in milk of sheep and goats grazing similar pastures in a semiarid region of Pakistan. Small Ruminant Research, 65, 274-278. doi:10.1016/j.smallrumres.2005.07.050

[16] McDowell, L.R. (1992) Minerals in animal and human nutrition. Academic Press, San Diego.

[17] Espinoza, J.E., McDowell, L.R., Wilkinson, N.S., Conrad, J.H. and Martin, F.G. (1991) Monthly variation of forage and soil minerals in Central Florida. II. Trace Minerals. Communications in Soil Science and Plant Analysis, 22, 1137-1149. doi:10.1080/00103629109368480

[18] Santana, R.R. and McDowell, L.R. (1994) Yield, in vitro digestibility, crude protein and mineral concentrations of eight Digitaria introductions in Puerto Rico. Communications in Soil Science and Plant Analysis, 25, 2019-2027. doi:10.1080/00103629409369169

[19] Fick, K.R., McDowell, L.R., Miles, P.H., Wilkinson, N.S., Funk, J.D. and Conrad, J.H. (1979) Methods of mineral analysis for plant and animal tissues. 2nd Edition, Department of Animal Sciences, University of Florida, Gainesville.

[20] Duncan, D.B. (1955) Multiple range and multiple F-test. Biometrics, 11, 1-42. doi:10.2307/3001478

[21] Underwood, E.J. (1981) The mineral nutrition of livestock. 2nd Edition, Commonwealth Agricultural Bureaux, Slough.

[22] Prabowo, A., McDowell, L.R., Wilkinson, N.S., Wilcox C.J. and Cornad, J.H. (1990) Mineral status of grazing cattle in South Sulawesi, Indonesia; I. Macrominerals. Asian-Australian Journal of Animal Science, 4, 111-120.

[23] Tiffany, M.E., McDowell, L.R., O’Connor, G.A., Nguyen, H., Martin, F.G., Wilkinson, N.S. and Katzowitz, N.A. (2001) Effects of residual and reapplied biosolids on forage and soil concentrations over a grazing season in north Florida. II. Microminerals. Communications in Soil Science and Plant Analysis, 32, 2211-2226. doi:10.1081/CSS-120000278

[24] Khan, Z.I., Ashraf, M., Hussain, A. and McDowell, L.R. (2005) Seasonal variation of trace elements in a semi-arid veld pasture. Communications in Soil Science and Plant Analysis, 37, 1471-1484. doi:10.1080/00103620600585914

[25] Islam, M.R., Saha, C.K., Sharker, N.R., Jahilil, M. and Hasanuzzaman, M. (2003) Effect of variety on proportion of botanical fraction and nutritive value of different Napier grass (Pennisetum puporeum) and relationship between botanical fraction and nutritive value. AsianAustralian Journal of Animal Science, 16, 177-188.

[26] Khan, Z.I., Hussain, I.A., Ashraf, M., Valeem, E.E. and Ahmad, M.S. (2004) Soil and forage (Trace elements) status of a grazing pasture in the semi-arid region of Pakistan. Pakistan Journal of Botany, 36, 851-856.

[27] McDowell, L.R., Houser, R.H. and Fick, K.R. (1978) Iron, zinc and manganese in ruminant nutrition. In: Conrad, J.R. and McDowell, L.R., Eds., Latin American symposium on Mineral Nutrition Research with Grazing Ruminants, University of Florida, Gainesville, 108-116.

[28] Serra, A.B., Serra, S.D., Orden, E.A., Cruz, L.C., Nakamura, K. and Fujihara, T. (1987) Variability in ash, crude protein, detergent fibre, and mineral content of some minor plant species collected from pastures grazed by goats. Asian-Australian Journal of Animal Science, 10, 28-34.

[29] Cuesta, P.A., McDowell, L.R., Kunkle, W.E., Bullock, F., Drew, A., Wilkinson, N.S. and Martin, F.G. (1993) Seasonal variation of soil and forage mineral concentrations in north Florida. Communications in Soil Science and Plant Analysis, 24, 335-347. doi:10.1080/00103629309368803

[30] Tejada, R., McDowell, L.R., Martin, F. G. and Conrad, L.H. (1987) Evaluation of the macro mineral and crude protein status of cattle in specific regions in Guatemala. Nutrition Reports International, 35, 989-998.

[31] Velasquez-Pereira, J.B., McDowell, L.R., Conrad, J.H., Wilkinson, N.S. and Martin, F.G. (1997) Mineral status of soils, forages, and cattle in Nicaragua. I. Micro-minerals. Revista de la Facultad de Agronomía, 14, 73-89.

[32] Kabata-Pendias, A. and Pendias, H. (1992) Trace elements in soils and plants. CRC Press Inc., Boca Raton.

[33] Khan, Z.I., Hussain, A., Ashraf, M., McDowell, L.R. and Huchzermeyer, B. (2007) Copper nutrition of goats grazing native and improved pasture with seasonal variation in a semiarid region of Pakistan. Small Ruminant Research, 67, 138-148. doi:10.1016/j.smallrumres.2005.09.030

[34] Khan, Z.I., Ashraf, M., Hussain, A. and McDowell, L.R. (2006) Concentrations of minerals in milk of sheep and goats grazing similar pastures in a semiarid region of Pakistan. Small Ruminant Research, 65, 274-278. doi:10.1016/j.smallrumres.2005.07.050

[35] Santana, R.R. and McDowell, L.R. (1994) Yield, in vitro digestibility, crude protein and mineral concentrations of eight Digitaria introductions in Puerto Rico. Communications in Soil Science and Plant Analysis, 25, 2019-2027. doi:10.1080/00103629409369169

[36] NRC (1985) Nutrient requirements of sheep. 6th Edition. National Research Council, National Academy Press, Washington DC.

[37] Masters, D.G., Paynter, D.I., Briegel, J., Baker, S.K., Purser, D.B. and Dost, M. (1996) Improving fodder in smallholder livestock production in Northern Pakistan, short communication. World Animal Review, 87, 74-77.

[38] NRC (1984) Nutrient requirements of domestic animals. Nutrient requirements of sheep. 6th Edition, National Academy of Science, Washington DC.

[39] Sial, M.A. (1991) Livestock production in PakistanPotentials and challenges. Progressive Farming, 11, 7-14.

[40] Tudsri, S. and Kaewkunya, C. (2002) Effect of Leucaena row spacing and cutting intensity on growth of Leucaena 
and three associated grasses in Thailand. Asian-Australian Journal of Animal Science, 15, 986-991.

[41] Aregheore, E.M. (2002) Voluntary intake and digestibility of fresh, wilted and dry Leucaena (Leucaena leucochepala) at four levels to a basal diet of guinea grass (panicum maximum). Asian-Australian Journal of Animal Sciences, 15, 1139-1146.

[42] Morris, J. G. (1980) Assessment of sodium requirements of grazing beef cattle. Journal of Animal Science, 50, 145-152.

[43] ARC (1980) The nutrients requirements of ruminant livestock. 4th Edition, CAB International, Wallingford.

[44] McDowell, L.R., Conrad, J.H. and Hembry, F.G. (1993) Minerals for grazing ruminants in tropical regions. University of Florida, Gainseville.

[45] Khan, Z.I., Ashraf, M., Javed I. and Ermidou-Pollet, S. (2007) Transfer of sodium from soil and forage to sheep and goats grazing in a semiarid region of Pakistan. Influence of the seasons. Trace Elements and Electrolytes, 24, 49-54.

[46] Kim, G.D., Kim, S.G., Abuel, S.J., Kwon, C.H., Shin, C.N. and Ko, K.H. (2006) Effect of location, season, and variety on yield and quality of forage oat. Asian-Australian Journal of Animal Science, 19, 970-977.

[47] Underwood, E.J. and Suttle, N.F. (1999) The mineral nutrition of livestock. 3rd Edition, CAB International, Wallingford.

[48] Reuter, D.J. and Robinson, J.B. (1997) Plant analysis. An interpretation manual. 2nd Edition, CSIRO Publishing, Melbourne.

[49] Pastrana, R., McDowell, L.R., Conrad, J.H. and Wilkinson, N.S. (1991) Mineral status of sheep in the Paramo region of Colombia. II. Trace minerals. Small Ruminant Research, 5, 23-34. doi:10.1016/0921-4488(91)90027-N

[50] Khan, Z.I., Hussain, A., Ashraf, M. and Ermidou-Pollet, S. (2007) Transfer of iron from soil and forage to sheep grazing in a semiarid region of Pakistan. Influence of the seasons and the period of sampling. Trace Elements and Electrolytes, 42, 166-172.

[51] Meschy, F. (2000) Recent progress in the assessment of mineral requirements of goats, livestock. Livestock Production Science, 64, 1-14.

doi:10.1016/S0301-6226(00)00171-8

[52] Salih, Y.M., McDowell, L.R., Hentges, J.F., Mason R.M. and Conrad, J.H. (1983) Mineral status of grazing beef cattle in the warm climate region of Florida. Tropical Animal Health and Production, 15, 245-251. doi:10.1007/BF02242070

[53] Judson, G.J. and McFarlane, J.D. (1998) Mineral disorders in grazing livestock and the usefulness of soil and plant analysis in the assessment of these disorders. Australian Journal of Experimental Agriculture, 38, 707723. doi:10.1071/EA97145

[54] Dua, K. and Care, A.D. (1995) Impaired absorption of magnesium in the etiology of grass tetany. British Veterinary Journal, 151, 413-426. doi:10.1016/S0007-1935(95)80130-8

[55] Cox, F.R. (1973) Micronutrients. In: Sánchez, P.A., Ed., A Review of Soil Research in Tropical Latin America, North Carolina Agricultural Experimental Statistics, Raleigh, 182-189.

[56] Healy, W.B. (1973) Nutritional aspects of soil ingestion by grazing animals' herbage. 1, Academic Press, London, 567-588.

[57] Rojas, L.X., McDowell, L.R., Wilkinson, N.S. and Martin, F.G. (1993) Mineral status of soils, forages and beef cattle in South-Eastern Venezuela. II. Microminerals. International Journal of Animal Science, 8, 183-188.

[58] McDowell, L.R. (1996) Feeding minerals to cattle on pasture. Animal Feed Science and Technology, 60, 247271. doi:10.1016/0377-8401(96)00983-2

[59] Khan, Z.I., Hussain, I.A., Ashraf, M. and McDowell, L.R. (2008) Assessment and comparison of blood plasma mineral concentrations of different classes of grazing sheep. Trace Elements and Electrolytes, 25, 7-13.

[60] Khan, Z.I., Hussain, A., Ashraf, M., Ashraf, M.Y. and McDowell, L.R. (2005) Macro mineral status of grazing sheep in Punjab, Pakistan. Small Ruminant Research, 68, 279-284. doi:10.1016/j.smallrumres.2005.11.003 